\title{
Diversity of Bacterial Isolates from Commercial and Homemade Composts
}

\author{
Ivone Vaz-Moreira • Maria E. Silva • Célia M. Manaia • \\ Olga C. Nunes
}

I. Vaz-Moreira $\cdot$ C. M. Manaia

Escola Superior de Biotecnologia, Universidade Católica

Portuguesa, 4200-072 Porto, Portugal

M. E. Silva

Escola Superior de Tecnologia de Viseu,

Instituto Politécnico de Viseu, 3504-510 Viseu, Portugal

\begin{abstract}
The diversity of heterotrophic bacterial isolates of three commercial and two homemade composts was studied. The commercial composts were produced from poultry litter (PC), sewage sludge (SC), municipal solid waste (MC), and homemade composts (thermal compost [DC] and vermicompost [VC]) from food wastes. The taxonomic and physiological diversity of the heterotrophic culturable bacteria was assessed using phenotypic and genotypic characterization and the analysis of the partial 16S rRNA gene sequence. Composts DC and SC presented the higher genotypic diversity, as could be inferred from the number of distinct genotypic patterns observed, 28 and 21, respectively. Gram-positive bacteria, mainly Firmicutes, were predominant in all the composts. Some organisms related with taxa rarely reported in composts, as Rhodanobacter spathiphylli, Moraxella osloensis, Lysobacter, Corynebacterium, Pigmentiphaga kullae, and new taxa were also isolated. The highest relative proportion of isolates able to degrade starch was found in compost SC $(>70 \%)$, to degrade gelatine in compost DC $(>70 \%)$, to degrade Tween 80 in compost PC $(>90 \%)$, and to degrade poly-epsilon-caprolactones in compost DC (>80\%). Compost $\mathrm{MC}$ presented the lowest relative proportions of isolates able to degrade starch $(<25 \%)$, gelatine $(<20 \%)$, and poly-epsilon-caprolactone $(<40 \%)$. When compared with the others, the homemade composts presented higher relative proportions of Gram-positive isolates able to inhibit the target organisms Staphylococcus aureus, Enterococcus
\end{abstract}

faecalis, Escherichia coli, or Pseudomonas aeruginosa. In compost MC, none of the Gram-positive isolates was able to inhibit those targets.

\section{Introduction}

Composting involves the biological decomposition of organic matter under aerobic conditions to produce a humus-like product. Residues such as yard waste, manure, sewage sludge, municipal solid waste or industrial waste are recycled worldwide through field scale composting $[2,9]$. The recycling of the domestic organic waste through home composting is also practiced worldwide, contributing to the increased level of environmental awareness [7]. Compost products are used in agriculture, forest or ornamental farming and as landfill cover in public areas as parks or sport fields $[2,19]$. Previous studies show that compost microbiota is rather complex and that the use of culture-dependent and independent methods may reveal different members of these communities [1, 13]. Whereas bacilli and other spore-forming bacteria are the predominant culturable bacteria found in composts [1, 12-14], total DNA-based studies indicate the prevalence of other organisms. Using culture-independent approaches, Fracchia et al. [6] observed the prevalence of Gram-positive organisms belonging to the Firmicutes and to the Actinobacteria. Takaku et al. [13] registered a shift of the 
prevalence of Firmicutes during the thermophilic stage to Bacteroidetes in the maturing phase. In one of the few studies reporting the bacterial diversity of finished composts, Fracchia et al. [6] underline also the contrast between hot compost and vermicompost. In vermicompost, they found the predominance of members of the phyla Chloroflexi, Acidobacteria, Bacteroidetes, and Gemmatimonadetes. These results suggest that although some taxa have a widespread presence in composts, others may be more or less abundant according to the nature of raw materials, composting conditions, and maturation process $[2,6,13]$.

Compost is the final product of an extensive process of biological decomposition of organic residues with increased bioavailability of nutrients and reduced pathogen presence [2]. Microorganisms able to degrade polymers through the production of extracellular enzymes or to inhibit pathogens may have a selective advantage during the composting process. Their presence in the finished product is important, reflecting somehow the compost quality, and its properties as nutrient supplier and pathogen suppressor.

The present work aimed at the comparison of the diversity of heterotrophic bacteria isolated from three commercial and two homemade finished composts considered by the respective producers as ready-to-use. The production of extracellular amylases, proteases, lipases, esterases, and antimicrobial agents was assessed in the culturable heterotrophic bacteria, and their genotypic diversity was compared in the five compost products.

\section{Materials and Methods}

\section{Composts}

Three commercial composts, produced from poultry litter (PC), sewage sludge (SC) and municipal solid waste (MC), and two homemade composts, a thermal compost (DC) and a vermicompost (VC), were analyzed. The homemade composts were produced by an environmentalist group with the aim of promoting environmental awareness to students. Both homemade composts were produced from kitchen refuse, and neither the composting conditions nor the maturation state were controlled. When composting is considered complete (through visual examination), the recycled products are used for gardening without any further control. Compost DC was produced by thermal digestion in a wood-made domestic composter $\left(1 \mathrm{~m}^{3}\right)$ and compost VC was produced with the earthworm Eisenia foetida. The sewage sludge compost (SC) was produced from anaerobically digested sewage sludge of a domestic wastewater treatment plant as described before [14]. The poultry litter compost (PC) was produced from chicken wastes of aviaries, meat meal, bird bones, vegetal ashes, and grape husk. The materials were stored for 5-6 months till its composting. The composting process was conducted in piles (20 m length, $10 \mathrm{~m}$ wide, and $4 \mathrm{~m}$ height), under a covered area for a period of 45 days with mechanical revolving. The municipal solid waste compost (MC) was produced from undifferentiated urban wastes. These wastes were initially submitted to a coarse selection and to a precomposting of 3 days in an aerated bioreactor (DANO). After precomposting, which facilitates the separation of the organic matter from other inert materials, the composting process occurred at open field for 6-7 weeks in piles with automatic aeration and revolving. A package of compost (SC, PC, or MC) was purchased in the commercial department of the respective producer. According to the label information, these commercial composts are recommended as potting soil, for gardening and agriculture (SC), vineyards and orchards (MC), or vineyards, orchards, and olive groves (PC).

\section{Physicochemical Analysis}

The physicochemical properties of the composts studied (Table 1) were determined using standard procedures, as described before [11]. Water extracts of the compost were obtained by mechanically shaking the samples with distilled water at 1:5 $(w / v)$ for $1 \mathrm{~h}$. The suspensions' glass wool filtrates were used for the determination of electrical conductivity and $\mathrm{pH}$. Moisture content was determined in compost samples dried at $105^{\circ} \mathrm{C}$ for $4 \mathrm{~h}$. The concentration of volatile solids (organic matter) was determined as the gravimetric loss-on-ignition produced by ashing the previously dried samples at $550^{\circ} \mathrm{C}$ for $8 \mathrm{~h}$. Total nitrogen content was obtained by the Kjeldahl digestion method, and total carbon was estimated by multiplying the organic matter content by 0.5 . $\mathrm{NH}_{4}{ }^{+}$-nitrogen was determined after extraction with $2 \mathrm{~N} \mathrm{KCl}($ ratio $1: 4, w / v)$ for $1 \mathrm{~h}$, centrifugation at $3,500 \mathrm{rpm}$ for $30 \mathrm{~min}$, filtration, distillation, and titration with $0.05 \mathrm{~N} \mathrm{HCl}$. The $\mathrm{C} / \mathrm{N}$ ratio was calculated based on the concentration of total carbon and total nitrogen. The heavy metals content $(\mathrm{Cd}, \mathrm{Cr}, \mathrm{Cu}, \mathrm{Ni}, \mathrm{Pb}$, and $\mathrm{Zn})$ was determined by flame atomic absorption spectrometry (PerkinElmer Atomic Absorption Spectrophotometer) after filtering the extracts obtained from the digestion of the ashes with $3 \mathrm{~N} \mathrm{HCl}$. The physicochemical analyses were done in triplicate. The self-heating bioassay was performed using $1 \mathrm{~kg}$ of the sample adjusted to $35 \%$ of moisture content in a Dewar vessel. The germination index was performed using aqueous extracts of compost obtained by mechanically shaking dried samples with sterilized water (ratio $1: 10, w / v$ ) for $1 \mathrm{~h}$. The suspensions were centrifuged at 3,500 rpm for $20 \mathrm{~min}$ and filtered. About $1.0 \mathrm{~mL}$ of each filtrate or water, as control, was added to a sterile plastic petri dish lined with Whatman \# 2 filter paper. Fifteen 
Table 1 Physicochemical characterization of the composts

\begin{tabular}{|c|c|c|c|c|c|}
\hline Compost & $\begin{array}{l}\text { Vermicompost } \\
(\mathrm{VC})^{\mathrm{a}}\end{array}$ & $\begin{array}{l}\text { Domestic wastes } \\
(\mathrm{DC})^{\mathrm{a}}\end{array}$ & $\begin{array}{l}\text { Sewage sludge } \\
\text { (SC) }\end{array}$ & $\begin{array}{l}\text { Poultry litter } \\
(\mathrm{PC})\end{array}$ & $\begin{array}{l}\text { Municipal residues } \\
\text { (MC) }\end{array}$ \\
\hline $\mathrm{pH}$ & 6.5 & 6.8 & 4.2 & 9.0 & 5.6 \\
\hline Conductivity $\left(\mathrm{mS} \mathrm{cm}^{-1}\right)$ & 8.0 & 0.5 & 1.6 & 7.6 & 10.9 \\
\hline Moisture content $(\%)$ & 9.5 & 36.2 & 59.6 & 24.7 & 45.5 \\
\hline Organic matter (\%) & 31.4 & 38.3 & 82.4 & 46.8 & 73.3 \\
\hline Total carbon (\%) & 15.7 & 19.2 & 42.2 & 23.4 & 36.7 \\
\hline$N$ total Kjeldahl (\%) & 1.3 & 1.5 & 1.4 & 2.5 & 1.3 \\
\hline $\mathrm{C} / \mathrm{N}$ ratio & 12.1 & 12.8 & 31.0 & 9.2 & 29.4 \\
\hline $\mathrm{N}-\mathrm{NH}_{4}^{+}$(g kg ${ }^{-1}$ dry weight $)$ & 0.07 & $<\mathrm{LD}$ & 0.06 & 2.9 & 2.1 \\
\hline \multicolumn{6}{|l|}{ Heavy metals (mg kg ${ }^{-1} \mathrm{~ms}$ ) } \\
\hline $\mathrm{Zn}$ & 172 & 393 & 637 & 646 & 820 \\
\hline $\mathrm{Cu}$ & 68 & 90 & 299 & 86 & 285 \\
\hline $\mathrm{Ni}$ & 39 & 20 & 38 & 19 & 61 \\
\hline $\mathrm{Cd}$ & 0.7 & 1.1 & 1.9 & 1.2 & 1.3 \\
\hline $\mathrm{Cr}$ & 47 & 42 & 62.3 & 30 & 213 \\
\hline $\mathrm{Pb}$ & 61 & 59 & 79 & 149 & 219 \\
\hline Self-heating test & n.d. & $\mathrm{V}$ & V & III & $\mathrm{V}$ \\
\hline Germination index $(\%)$ - cress & 64 & 112 & 67 & 0 & 1 \\
\hline
\end{tabular}

$L D$ : limit of detection $=0.04 \mathrm{mg} \mathrm{kg}^{-1}$ (wet weight), n.d.: not determined.

${ }^{a}$ Given the fact that homemade composts are produced at a very small scale, it was not possible to analyze the physicochemical properties in the same bulk of compost used for the microbiological study.

plastic petri dishes were used for each filtrate where seven cress seeds (Lepidium sativum L.) were placed on the filter and incubated at $27^{\circ} \mathrm{C}$ for $24 \mathrm{~h}$. The germination index was calculated based on the number of germinated seeds and the measure of the length of roots according to the following formula:

Germination index $(\%)$

$$
\begin{aligned}
= & \frac{\text { seed germination }(\%) \times \text { root length of treatment }}{\text { Seed germination }(\%) \times \text { root length of control }} \\
& \times 100
\end{aligned}
$$

\section{Enumeration and Isolation of Microorganisms}

Microbial analyses were performed using the membrane filtration method. Compost suspensions of $10 \mathrm{~g}$ of compost and $90 \mathrm{~mL}$ of sterile saline solution $(0.85 \%(w / v) \mathrm{NaCl})$ were shaken for $30 \mathrm{~min}$ and serially diluted $\left(10^{-1}\right.$ to $\left.10^{-7}\right)$. A volume of $1 \mathrm{~mL}$ of each dilution was filtered (cellulose nitrate, $0.45 \mu \mathrm{m}$ pore size, $47 \mathrm{~mm}$ diameter; Albet) and the membranes placed onto five different culture media: plate count agar (PCA, Merck) for total heterotrophs, levine EMB agar (Oxoid) for total coliforms, $m$-Enterococcus agar (Difco) for enterococci, actinomycete isolation agar (Difco) for actinomycetes, and Rose Bengal agar (Merck) for fungi. Colony forming units (CFU) were enumerated after the respective incubation periods: $24 \mathrm{~h}$ at $30^{\circ} \mathrm{C}$ for total heterotrophs; 7 days at $30^{\circ} \mathrm{C}$ for actinomycetes; $24 \mathrm{~h}$ at $35^{\circ} \mathrm{C}$ for total coliforms; $48 \mathrm{~h}$ at $35^{\circ} \mathrm{C}$ for enterococci; and 7 days at $22^{\circ} \mathrm{C}$ for fungi. Typical colonies of coliforms were confirmed as fecal coliforms when grew and produced gas in Escherichia coli medium (EC; Difco) after $24 \mathrm{~h}$ at $45^{\circ} \mathrm{C}$. Catalase negative isolates from the $m$-Enterococcus medium, capable of producing darkening on bile esculin agar (BEA; Merck), after incubation at $35^{\circ} \mathrm{C}$, were confirmed as enterococci. To evaluate the diversity of culturable heterotrophic bacteria from the analyzed composts, $1-5$ colonies of each morphotype grown on PCA were purified and further characterized. In total, 239 colonies were recovered-36 from VC, 55 from DC, 61 from SC, 54 from PC, and 33 from MC. Among these, 5 were yeasts ( 3 from compost VC and 2 from SC) and 19 were lost during the purification process ( 2 from compost $\mathrm{SC}, 1$ from $\mathrm{PC}$, and 16 from $\mathrm{MC}$ ). The pure cultures were cryopreserved in nutrient broth (NB; Merck) supplemented with $15 \%(v / v)$ glycerol (Merck).

\section{Phenotypic Characterization of the PCA Isolates}

Each isolate was characterized for colony and cell morphology, Gram staining, presence of endospores, presence of catalase, and presence of Cytochrome $c$ oxidase. The ability of each purified isolate to degrade the polymeric substrates starch, gelatine, Tween 80 , and poly-epsiloncaprolactone (PCL) was assessed as described before [14]. 
Yeasts, occasionally isolated on PCA, were characterized using the API ID 32C (BioMérieux, Marcy l'Etoile, France) according to the manufacturer's instructions. Gram-positive rods were assayed for antimicrobial activity, using the perpendicular streak method [20]. The target cultures were E. coli ATCC 25922, Enterococcus faecalis DSM 2570, Pseudomonas aeruginosa DSM 1117, and Staphylococcus aureus DSM 1104, references for antibiogram testing quality control. Test cultures were heavily inoculated in half petri plate of PCA and incubated for $24 \mathrm{~h}$ at $30^{\circ} \mathrm{C}$. A cell suspension of each target culture with a turbidity of 0.2 at $610 \mathrm{~nm}$ was dispensed in a row of four spots of $3 \mu \mathrm{L}$ each, perpendicular to the test culture and incubated for $24 \mathrm{~h}$ at $30^{\circ} \mathrm{C}$. The absence of growth in one or more of the four spots indicated a positive result. Reproducibility was assessed testing in duplicate approximately $20 \%$ of the randomly selected cultures.

\section{Genotypic Characterization}

Random amplified polymorphic DNA (RAPD) and repetitive extragenic palindromic (REP) analyses were used to genotype and to group the bacterial isolates. Based on preliminary assays, it was decided which of the typing methods gave a rich and well-resolved fingerprinting pattern for Gram-positive rods, Gram-negative rods, and Gram-positive cocci. After this preliminary assay, 47 isolates were typed with REP and 168 were typed with RAPD. About 32 isolates were typed using both methods and gave concordant results. Total DNA from crude cell lysates was used for the genotypic analysis. REP reactions were performed in a total volume of $25 \mu \mathrm{L}$ containing: $1 \mathrm{x}$ $\left(\mathrm{NH}_{4}\right)_{2} \mathrm{SO}_{4}$ Taq buffer, $1.5 \mathrm{mM} \mathrm{MgCl} 2,0.2 \mathrm{mM}$ of each dNTP, 1U Taq polymerase (Pharmacia Biotech), $2 \mu \mathrm{L}$ of DMSO, $1 \mu \mathrm{L}$ of bovine serum albumin $(1 \%, w / v), 2 \mathrm{pmol} /$ $\mu \mathrm{L}$ of each primer REP1R-I and REP2-I [18], and $1 \mu \mathrm{L}$ of crude cell lysate. After $2 \mathrm{~min}$ at $95^{\circ} \mathrm{C}$, the samples were subjected to 35 cycles of amplification as follows: $1 \mathrm{~min}$ at $94^{\circ} \mathrm{C}, 1 \mathrm{~min}$ at $40^{\circ} \mathrm{C}, 3 \mathrm{~min}$ at $70^{\circ} \mathrm{C}$, and a final extension step of $8 \mathrm{~min}$ at $65^{\circ} \mathrm{C}$. RAPD reactions were performed as described by Ferreira da Silva et al. [4], using the primers M13 (5'GAGGGTGGCGGTTCT3') or OPA3 (5'AGTCA GCCAC3'). Polymorphic DNA fragments from REP or RAPD were analyzed after electrophoresis in a $1.5 \%$ agarose gel in Tris-acetate-EDTA (TAE) buffer, and the genotypic patterns were compared visually. Each resemblance group was formed by isolates with genotypic patterns differing by $2-3$ bands. About $30 \%$ of the isolates (at least $10-15 \%$ of each REP- or RAPD-based group) were further characterized by $16 \mathrm{~S}$ rRNA gene sequence analysis. The $16 \mathrm{~S}$ rRNA gene was amplified and the sequences corresponding to the first $800 \mathrm{bp}$ were compared with others available in public databases [5].

\section{Results}

Although the age and maturity might differ among the five composts analyzed, these products were sold or supplied by the producers as being ready-to-use. The comparison of the results obtained for the different composts, made throughout this report, is based on such assumption. Total heterotrophs, coliforms, enterococci, actinomycetes, and fungi were enumerated in the different composts (Table 2). Higher counts of total heterotrophs, actinomycetes, and fungi were observed in homemade than in commercial composts. The kitchen refuse homemade compost (DC) was the only product where fecal coliforms were detected, and presented the highest counts of all bacterial groups, except enterococci. In contrast, the lowest bacterial and fungal counts were determined for municipal wastes compost (MC). Enterococci were the least prevalent bacterial group in all the composts, being more abundant in the poultry litter compost (PC).

Considering that the diversity of the total heterotrophs would reflect the bacterial variety of culturable organisms present in each compost, the isolates recovered on PCA were purified and further characterized. Although the use of culture media with $\mathrm{pH}$ values close to those observed in each compost could have maximized the isolation of

Table 2 Enumeration of cultivable bacteria and fungi $\left(\mathrm{CFU} \mathrm{g}{ }^{-1}\right)$ of the analyzed composts

\begin{tabular}{|c|c|c|c|c|c|}
\hline Compost & $\begin{array}{l}\text { Vermicompost } \\
\text { (VC) }\end{array}$ & $\begin{array}{l}\text { Domestic wastes } \\
\text { (DC) }\end{array}$ & $\begin{array}{l}\text { Sewage sludge } \\
\text { (SC) }\end{array}$ & $\begin{array}{l}\text { Poultry litter } \\
\text { (PC) }\end{array}$ & $\begin{array}{l}\text { Municipal residues } \\
\text { (MC) }\end{array}$ \\
\hline Total heterotrophs $\left(\times 10^{6}\right)$ & 3.8 & 44.0 & 0.7 & 0.5 & 0.05 \\
\hline Total coliforms $\left(\times 10^{5}\right)$ & 0.6 & 5.5 & 0.7 & 0.6 & 0.005 \\
\hline Fecal coliforms & - & + & - & - & - \\
\hline Enterococci $\left(\times 10^{4}\right)$ & $<0.001$ & 0.1 & 0.005 & 4.0 & $<0.001$ \\
\hline Actinomycetes $\left(\times 10^{6}\right)$ & 12.0 & 22.5 & 0.1 & 9.0 & 0.03 \\
\hline Fungi $\left(\times 10^{5}\right)$ & 12.5 & 6.0 & 0.70 & 0.008 & 0.0005 \\
\hline
\end{tabular}


Figure 1 Relative percentages of isolates producing extracellular enzymes able to degrade gelatine, starch, Tween 80 , or poly-epsilon-caprolactones. Positive reactions were indicated by gelatine liquefaction and the occurrence of a degradation halo around the bacterial biomass in starch-, Tween $80-$, or PCL-enriched agar medium

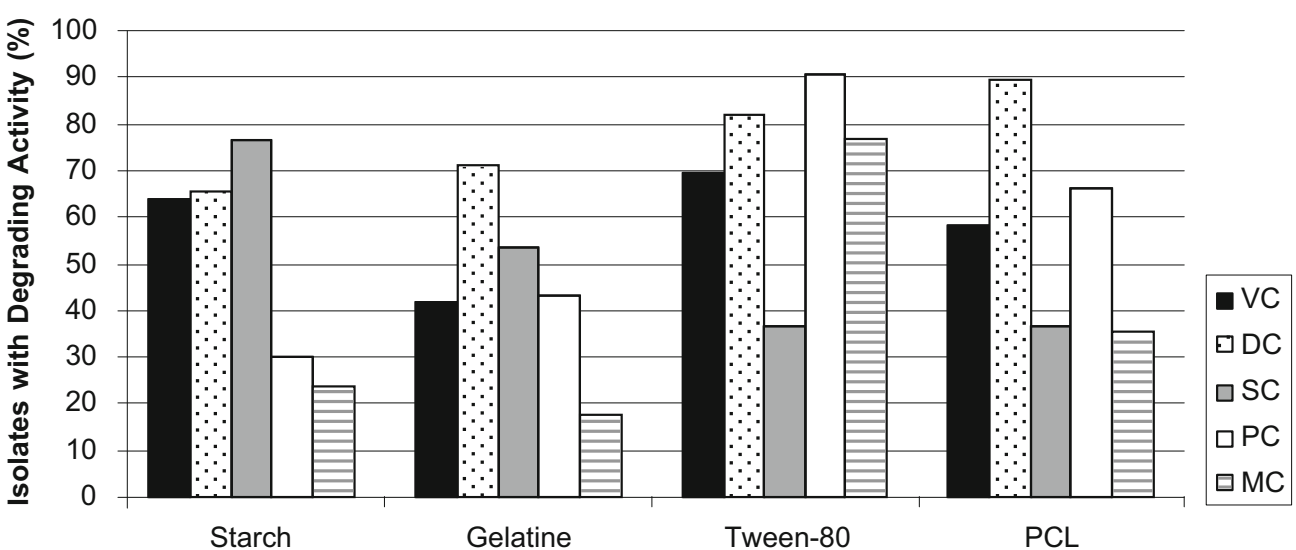

To assess the physiological properties of the compost bacterial isolates, the production of extracellular amylases, proteases, lipases, and/or esterases was examined using the substrates starch, gelatine, Tween 80 , and poly-epsiloncaprolactone polyesters (PCL), respectively (Fig. 1). In general, compost DC presented the highest frequency of isolates with extracellular enzymatic activity, whereas the lowest was found in MC. Except in compost SC, Tween 80 degraders presented frequencies ranging from $70 \%$ to $90 \%$ in all the composts, being this, the substrate more frequently degraded by compost isolates. PCL and Tween 80 degraders were in approximate frequencies in composts DC and SC. The percentage of amylase producers was
Table 3 Antimicrobial activity of Gram-positive rods isolated from the composts against the target organisms: (1) E. coli ATCC 25922, (2) E. faecalis DSM 2570, (3) P. aeruginosa DSM 1117, and (4) S. aureus DSM 1104

None of the isolates from compost MC evidenced antimicrobial activity. $n$ : number of isolates tested, black: positive, white: negative

\begin{tabular}{|c|c|c|c|c|}
\hline \multirow{2}{*}{ Compost } & \multicolumn{3}{|c|}{ Antimicrobial activity against } & \multirow{2}{*}{$\begin{array}{l}\text { Frequency, \% } \\
\left(\mathrm{n}^{\circ} \text { isolates } / \mathrm{n}\right)\end{array}$} \\
\hline & \begin{tabular}{l|l|}
1 & 2 \\
\end{tabular} & 3 & 4 & \\
\hline \multirow{3}{*}{$\begin{array}{c}\mathrm{VC} \\
(\mathrm{n}=22)\end{array}$} & & & & $13.6(3 / 22)$ \\
\hline & & & & $9.1(2 / 22)$ \\
\hline & & & & $9.1(2 / 22)$ \\
\hline \multirow{6}{*}{$\begin{array}{c}\text { DC } \\
(n=42)\end{array}$} & & & & $7.1(3 / 42)$ \\
\hline & & & & $2.4(1 / 42)$ \\
\hline & & & & $2.4(1 / 42)$ \\
\hline & & & & $7.1(3 / 42)$ \\
\hline & & & & $4.8(2 / 42)$ \\
\hline & & & & $4.8(2 / 42)$ \\
\hline \multirow{4}{*}{$\begin{array}{c}\mathrm{SC} \\
(\mathrm{n}=48)\end{array}$} & & & & $4.2(2 / 48)$ \\
\hline & & & & $2.1(1 / 48)$ \\
\hline & & & & $2.1(1 / 48)$ \\
\hline & & & & $2.1(1 / 48)$ \\
\hline \multirow{3}{*}{$\begin{array}{c}\mathrm{PC} \\
(\mathrm{n}=20)\end{array}$} & & & & $10.0(2 / 20)$ \\
\hline & & & & $5.0(1 / 20)$ \\
\hline & & & & $5.0(1 / 20)$ \\
\hline
\end{tabular}


above $60 \%$ in composts $\mathrm{DC}, \mathrm{VC}$, and $\mathrm{SC}$ and was considerably lower in the composts PC and MC (30\% and $24 \%$, respectively). Gelatine was degraded by only $18 \%$ of the $\mathrm{MC}$ isolates and by more than $40 \%$ of the bacteria from other composts.

The potential antimicrobial activity of Gram-positive rods isolated from the different composts was assayed against four reference organisms. Except for compost MC where no antimicrobial activity was detected, approximately $20 \%$ of Gram-positive rods were able to inhibit one or more of the targets tested (Table 3). Compost DC showed the highest diversity of bacteria with antimicrobial activity with $E$. coli ATCC 25922 and S. aureus DSM 1104 representing the most relevant targets. None of the $\mathrm{VC}$ isolates that exhibited antimicrobial activity was active against the Gram-negative targets tested. One isolate from compost PC, identified as Bacillus pumilus, exhibited antimicrobial activity against all the reference strains tested.

The genotyping of the isolates permitted both the assessment of compost bacterial diversity and the identification

Table 4 Taxonomic and physiological characterization of culturable bacteria from composts VC, DC, SC, PC, and MC

\begin{tabular}{|c|c|c|c|c|c|c|c|c|c|c|c|}
\hline \multirow[t]{2}{*}{ Taxa } & \multirow{2}{*}{$\begin{array}{l}\text { Accession number } \\
\text { (\% 16S rRNA gene } \\
\text { similarity) }\end{array}$} & \multicolumn{5}{|c|}{ Physiological activity } & \multicolumn{5}{|c|}{ Frequency $(\%)$} \\
\hline & & $\mathrm{S}$ & $\mathrm{G}$ & $\mathrm{T}$ & $\mathrm{P}$ & A & $\mathrm{VC}$ & DC & $\mathrm{SC}$ & $\mathrm{PC}$ & $\mathrm{MC}$ \\
\hline Firmicutes & & & & & & & $\begin{array}{l}60.6 \\
(20 / 33)\end{array}$ & $\begin{array}{l}69.0 \\
(38 / 55)\end{array}$ & $\begin{array}{l}59.7 \\
(34 / 57)\end{array}$ & $\begin{array}{l}90.6 \\
(48 / 53)\end{array}$ & $\begin{array}{l}35.4 \\
(6 / 17)\end{array}$ \\
\hline Bacillus bataviensis & AJ542508 (98\%) & + & - & - & - & - & & & 21.0 & & \\
\hline Bacillus benzoevorans & DQ298114 (100\%) & - & - & - & - & - & $6.1^{\mathrm{a}}$ & & & & \\
\hline Bacillus cereus group & AJ491706 (99\%) & + & + & + & + & - & 15.1 & $9.1^{\mathrm{a}}$ & $3.5^{\mathrm{a}}$ & & \\
\hline Bacillus fusiformis & AB167230 (100\%) & - & - & + & + & - & & $3.6^{\mathrm{a}}$ & & & 5.9 \\
\hline Bacillus licheniformis & СР000002 (99\%) & + & + & + & + & - & 3.0 & 12.7 & & 1.9 & 11.8 \\
\hline Bacillus megaterium & AJ717381 (100\%) & + & + & $\mathrm{v}$ & + & $\mathrm{v}$ & 6.1 & $5.5^{\mathrm{a}}$ & $3.5^{\mathrm{a}}$ & & \\
\hline Bacillus pumilus & AB098578 (100\%) & - & $\mathrm{v}$ & + & + & $\mathrm{v}$ & 6.1 & $10.9^{\mathrm{b}}$ & 1.8 & 9.4 & \\
\hline Bacillus subtilis & AY162133 (99\%) & + & + & $\mathrm{v}$ & + & $\mathrm{v}$ & $12.1^{\mathrm{a}}$ & 20.0 & $15.8^{\mathrm{a}}$ & 3.8 & \\
\hline Bacillus spp. & AY188840 (100\%) & - & + & + & + & $\mathrm{v}$ & & 3.6 & & & \\
\hline "Bacillus macroides" & AJ491708 (100\%) & $\mathrm{v}$ & - & + & $\mathrm{v}$ & - & 12.1 & 1.8 & & & \\
\hline Paenibacillus pasadenensis & AY167820 (98\%) & + & + & + & - & - & & & & 18.9 & \\
\hline Paenibacillus kobensis & D78471 (97\%) & + & - & + & - & $\mathrm{v}$ & & & $12.3^{\mathrm{a}}$ & & \\
\hline Paenibacillus spp. & AY397772 (99\%) & - & - & - & - & - & & & & & $11.8^{\mathrm{a}}$ \\
\hline Staphylococcus spp. & c & - & $\mathrm{v}$ & + & $\mathrm{v}$ & n.d. & & 1.8 & 1.8 & 56.6 & 5.9 \\
\hline Actinobacteria & & & & & & & $\begin{array}{l}15.2 \\
(5 / 33)\end{array}$ & $\begin{array}{l}3.6 \\
(2 / 55)\end{array}$ & $\begin{array}{l}14.0 \\
(8 / 57)\end{array}$ & - & $\begin{array}{r}41.2 \\
(7 / 17)\end{array}$ \\
\hline Cellulosimicrobium cellulans & AY501363 (99\%) & + & - & + & - & - & 6.1 & & & & \\
\hline Corynebacterium flavescens & X84441 (97\%) & - & - & + & - & - & & & & & 41.2 \\
\hline Microbacterium oxydans & AJ717357 (99\%) & + & - & + & - & - & 3.0 & 1.8 & & & \\
\hline Microbacterium spp. & AB114267 (97\%) & $\mathrm{v}$ & $\mathrm{v}$ & $\mathrm{v}$ & - & - & 6.1 & 1.8 & $14.0^{\mathrm{a}}$ & & \\
\hline Proteobacteria & & & & & & & $\begin{array}{l}18.2 \\
(6 / 33)\end{array}$ & $\begin{array}{l}9.1 \\
(5 / 55)\end{array}$ & $\begin{array}{l}21.2 \\
(12 / 57)\end{array}$ & $\begin{array}{l}3.8 \\
(2 / 53)\end{array}$ & $\begin{array}{l}5.9 \\
(1 / 17)\end{array}$ \\
\hline Castellaniella defragrans & AF508102 (96\%) & - & - & - & - & n.d. & & & 3.5 & & \\
\hline Pseudomonas libaniensis & AF057645 (99\%) & $\mathrm{v}$ & - & - & $\mathrm{v}$ & n.d. & 9.1 & & 1.8 & & 5.9 \\
\hline Pseudomonas spp. & AY166908 (100\%) & $\mathrm{v}$ & $\mathrm{v}$ & + & $\mathrm{v}$ & n.d. & 9.1 & 9.1 & & 3.8 & \\
\hline Rhodanobacter spathiphylli & AM087226 (97\%) & - & + & + & - & n.d. & & & 5.3 & & \\
\hline Rhodanobacter lindaniclasticus & L76222 (99\%) & + & $\mathrm{v}$ & + & + & n.d. & & & 5.3 & & \\
\hline Rhodanobacter spp. & AF494542 (98\%) & $\mathrm{v}$ & - & + & $\mathrm{v}$ & n.d. & & & 5.3 & & \\
\hline Other ungrouped genotypes ${ }^{\mathrm{d}}$ & & & & & & & $\begin{array}{l}6.1 \\
(2 / 33)\end{array}$ & $\begin{array}{l}18.2 \\
(10 / 55)\end{array}$ & $\begin{array}{l}5.3 \\
(3 / 57)\end{array}$ & $\begin{array}{l}5.7 \\
(3 / 53)\end{array}$ & $\begin{array}{l}17.6 \\
(3 / 17)\end{array}$ \\
\hline
\end{tabular}

a Two different genotypes.

${ }^{\mathrm{b}}$ Four different genotypes.

${ }^{\mathrm{c}}$ These isolates were identified as: Staphylococcus simulans (D83373, 99\%), S. equorum (AF527483, 99\%), and S. cohnii (AJ717378, 100\%).

${ }^{\mathrm{d}}$ See text for details.

$S$ : starch, $G$ : gelatine, $T$ : Tween $80, P$ : PCL, $A$ : antimicrobial activity, $v$ : variable among isolates; $n . d$ : not determined. 
of the bacteria present in each product. To achieve this last objective, selected isolates of each genotypic group were identified through the 16S rRNA gene sequence analysis. These identifications are listed in Table 4. Some genotypic patterns were observed for a single strain and were designated as "other ungrouped genotypes" in Table 4. The number of distinct genotypes observed in a compost measured, somehow, the genotypic diversity of culturable bacteria present in each product. Using such criterion, compost DC exhibited the highest diversity of culturable bacteria with 28 genotypes (10 of which were ungrouped), followed by compost SC with 21 genotypes (3 ungrouped). A comparative lower diversity was found in the other composts. VC had 16 genotypes ( 2 ungrouped), MC had 10 genotypes (3 ungrouped), and $\mathrm{PC}$ had 9 genotypes (3 ungrouped).

The identification of the isolates showed that members of the phylum Firmicutes were predominant in the composts VC, DC, SC, and PC, whereas Actinobacteria were dominant in compost MC. Among the Firmicutes identified, members of different species of the genus Bacillus were present in all composts. The genus Paenibacillus was also represented by three different species, one of which representing the new species $P$. humicus [17], being $P$. pasadenensis its closest phylogenetic neighbor. Lower numbers of Actinobacteria species were found. Among these isolates, two presumably represent new taxa (VazMoreira et al., unpublished). Compost SC presented the highest diversity of Gram-negative bacteria, belonging to the phylum Proteobacteria.

The isolates referred as "other ungrouped genotypes" (Table 4) were identified as Sphingomonas sp. (AF177917, 98\% similarity) and Kocuria palustris (Y16263, 99\% similarity) in compost VC. Eight of the 10 ungrouped genotypes observed in compost DC corresponded to Lysobacter sp. (AB083480, 96\% similarity), Pseudosphingobacterium domesticum gen. nov. sp. nov. (AM407725) [16], Stenotrophomonas maltophilia (AJ131117, 99\% similarity), Rhizobium sp. (DQ898296, 100\% similarity), Bacillus badius (AY803745, 99\% similarity), Bacillus sonorensis (AF302124, 99\% similarity), "Corynebacterium cyclohexanicum" (AB210282, 98\% similarity), Streptomyces sp. (AJ519937, 99\% similarity). Two other isolates of this compost were not identified. In compost SC ungrouped isolates were identified as Alcaligenes sp. (AJ412685, 97\% similarity), Paenibacillus barengoltzii (AY167814, 97\% similarity), and Pigmentiphaga kullae (AF282916, 96\% similarity), and in compost PC as Moraxella osloensis (AF005190, 99\% similarity), Bacillus circulans (DQ374636, 98\% similarity), and Brevibacillus parabrevis (AB112714, 99\% similarity). The three isolates from compost MC were not identified.

\section{Discussion}

Homemade composts, when compared with the commercial products, presented higher counts of heterotrophic bacteria, actinomycetes, and fungi. These results may be because of both the milder conditions of home composting where temperatures do not exceed $45-50^{\circ} \mathrm{C}$ (pers. comm.) and the similarity of the $\mathrm{pH}$ of these composts and of the culture media used, which presumably favored the microbial recovery. Except for the heavy metal content, the remaining physicochemical parameters determined are approximately in the same order of magnitude for homemade and for commercial composts. Among the analyzed composts, MC exhibited the lowest microbial counts, a fact that may be because of electrical conductivity or the $\mathrm{Pb}$ and $\mathrm{Cr}$ contents, higher in this product than in the others analyzed (Table 1). The relative abundance of coliforms (coliforms/total heterotrophs) was higher in the two composts analyzed that use manure-derived substrates, SC and PC. When compared with the others, compost PC presented a distinct pattern of microbial groups, characterized by a higher relative proportion of actinomycetes and enterococci versus total heterotrophs and fungi. The presence of high counts of enterococci in poultry litter composts has been reported before [9] and may be responsible, as a result of competition, for the low counts of heterotrophic bacteria observed. The abundance of Actinobacteria may have an alternative explanation - given that this compost presents a $\mathrm{pH}$ of 9 (Table 1), which is too high for optimal fungi development, the filamentous bacteria may, under these circumstances, have a competitive advantage and thus present the observed overgrowth. Although, at a first glance, the absence of actinomycetes among the isolates purified for further analysis might seem unexpected, it is easily explained on the basis of the slower growth of these bacteria (7 days on actinomycetes isolation agar) when compared with those isolated from PCA after $24 \mathrm{~h}$ of growth. The physiological activity of the bacterial isolates was characterized on the basis of the production of extracellular enzymes and antimicrobial substances, which are important properties in compost microbiota $[10,15]$. The homemade composts showed higher percentages of isolates capable of hydrolyzing the different substrates tested. Similar observations were obtained for the antimicrobial activity of the Gram-positive isolates of these two composts. All the PC isolates exhibiting antimicrobial activity were able to inhibit the growth of E. faecalis. In this compost, where enterococci were abundant (Table 2), bacteria able to antagonize these Gram-positive cocci may have a selective advantage in comparison with other bacteria and, thus, become prevalent, explaining the observed results. Only three isolates, two from compost 
DC and one from compost PC, were able to inhibit the $P$. aeruginosa growth.

The highest number of distinct genotypic patterns was observed in compost DC. Moreover, the culturable microbiota of this compost showed high total heterotrophic bacterial counts and physiological activity. In contrast, composts $\mathrm{PC}$ and $\mathrm{MC}$, those with more restrictive physicochemical conditions (e.g., high $\mathrm{pH}$, high electrical conductivity, or high heavy metal content; Table 1) presented a comparatively reduced genotypic diversity. This observation is concordant with the low germination index (Table 1) observed for the same composts and with the high rate of organisms lost during purification of MC isolates (16/33). Bacteria belonging to the phylum Firmicutes were found to be predominant in all composts, except in MC where Actinobacteria were prevalent and from which only Grampositive bacteria were isolated. The predominance of Grampositive bacteria, both Firmicutes and Actinobacteria, in composts was referred before $[2,6]$ and may be attributed to the production of thermotolerant spores. Bacteria belonging to the genus Bacillus were present in all the composts and were dominant in composts VC, DC, and SC. Among the Bacillus species found, some were previously reported in composts, e.g., B. subtilis, B. licheniformis, and $B$. pumilus $[3,8,12,14]$. In general, the isolates of the genus Bacillus presented a wider degradative and antimicrobial activity. Staphylococci, also Firmicutes, were isolated from composts DC and SC, although in low numbers, and from PC, where represented the majority of the isolates. The abundance of staphylococci in mature composts is considered to be uncommon [8]. In fact, based on the self-heating test, compost PC was classified at degree III (Table 1), which indicates that this product might not be fully maturated [2].

Previous reports comparing culture-independent and culture-dependent methods to assess compost bacterial diversity have demonstrated that only a small proportion of the compost microbiota can be isolated $[1,13]$. Using a culture-independent approach, Takaku et al. [13] demonstrated that although Firmicutes may be prevalent during composting, Bacteroidetes are predominant in mature composts. In the present study, a single strain, Pseudosphingobacterium domesticum, belonging to this phylum was identified [16]. Although culture-independent methods have an unquestionable usefulness for the characterization of compost microbiota, culture-dependent methods, which permit the isolation and physiological characterization of compost bacteria, represent a valuable tool to assess their role within the bacterial community.
Acknowledgements The authors gratefully acknowledge Prof. Margarida Silva and Engr. Conceição Almeida of the Grupo de Estudos Ambientais of Escola Superior de Biotecnologia for supplying the homemade composts.

\section{References}

1. Dees PM, Ghiorse WC (2001) Microbial diversity in hot synthetic compost as revealed by PCR-amplified rRNA sequences from cultivated isolates and extracted DNA. FEMS Microbiol Ecol 35:207-216

2. Epstein E (1997) The Science of Composting. Technomic ${ }^{\circledR}$ Publication, Lancaster, PA, ISBN 1-56676-478-5

3. Fang M, Wong JMC (2000) Changes in thermophilic bacteria population and diversity during composting of coal fly ash and sewage sludge. Water Air Soil Pollut 124:333-343

4. Ferreira da Silva M, Tiago I, Veríssimo A, Boaventura AR, Nunes OC, Manaia CM (2006) Antibiotic resistance of enterococci and related bacteria in an urban wastewater treatment plant. FEMS Microbiol Ecol 55:322-329

5. Ferreira da Silva M, Vaz-Moreira I, Gonzalez-Pajuelo M, Nunes OC, Manaia CM (2007) Antimicrobial resistance patterns in Enterobacteriaceae isolated from an urban wastewater treatment plant. FEMS Microbiol Ecol 60:166-176

6. Fracchia L, Dohrmann AB, Martinotti MG, Tebbe CC (2006) Bacterial diversity in finished compost and vermicompost: differences revealed by cultivation-independent analyses of PCR-amplified 16S rRNA genes. Appl Microbiol Biotechnol 71: 942-952

7. Haruta S, Nakayama T, Nakamura K, Hemmi H, Ishii M, Igarashi Y, Nishino T (2005) Microbial diversity in biodegradation and reutilization processes of garbage (review). J Biosc Bioeng 99(1): $1-11$

8. Hassen A, Belguith K, Jedidi N, Cherif A, Cherif M, Boudabous A (2001) Microbial characterization during composting of municipal solid waste. Bioresour Technol 80:217-225

9. Lasaridi K, Protopapa I, Kotsou M, Pilidis G, Manios T, Kyriacou A (2006) Quality assessment of composts in the Greek market: the need for standards and quality assurance. J Environ Manag 80(1):56-65

10. Pietronave S, Fracchia L, Rinaldi M, Martinotti MG (2004) Influence of biotic and abiotic factors on human pathogens in a finished compost. Water Res 38:1963-1970

11. Silva E, Vaz-Moreira I, Silva C, Sarabando H, Nunes OC, Manaia CM, Cunha-Queda C (2006) A contribution for a quality study of several composts produced in Portugal - ORBIT 2006 biological waste management: from local to global. 5th International Conference, Weimar, Germany

12. Strom PF (1985) Identification of thermophilic bacteria in solidwaste composting. Appl Environ Microbiol 50:906-913

13. Takaku H, Kodaira S, Kimoto A, Nashimoto M, Takagi M (2006) Microbial communities in the garbage composting with rice hull as an amendment revealed by culture-dependent and independent approaches. J Biosci Bioeng 101:42-50

14. Tiago I, Teixeira I, Silva S, Chung P, Veríssimo A, Manaia CM (2004) Metabolic and genetic diversity of mesophilic and thermophilic bacteria isolated from composted municipal sludge on poly- $\varepsilon$-caprolactones. Curr Microbiol 49:407-414 
15. Tiquia SM (2002) Evolution of extracellular enzyme activities during manure composting. J Appl Microbiol 92(4):764-775

16. Vaz-Moreira I, Nobre MF, Nunes OC, Manaia CM (2007) Pseudosphingobacterium domesticum gen. nov., sp. nov., isolated from home-made compost. Int J Syst Evol Microbiol 57:15351538

17. Vaz-Moreira I, Faria C, Nobre MF, Schumann P, Nunes OC, Manaia CM (2007) Paenibacillus humicus, sp. nov., isolated from chicken poultry litter compost. Int J Syst Evol Microbiol (in press)
18. Versalovic K, Koeuth T, Lupski JR (1991) Distribution of repetitive DNA sequences in Eubacteria and application to fingerprinting of bacterial genomes. Nucleic Acids Res 19(24): 6823-6831

19. Wei Y, Fan Y, Wang M, Wang J (2000) Composting and compost application in China. Resour Conserv Recycl 30: 277-300

20. Yilmaz M, Soran H, Beyatli Y (2006) Antimicrobial activities of some Bacillus spp. strains isolated from the soil. Microbiol Res 161:127-131 